\title{
The Effect of Teacher Work Motivation and Compensation on the Performance of Elementary School Teachers at Cempaka Sub-District of OKU Timur District
}

\author{
Afrina Maya Lestari ${ }^{1 *}$, Bukman Lian ${ }^{1}$, Alhadi Yan Putra ${ }^{1}$ \\ ${ }^{1}$ Universitas PGRI Palembang, Indonesia \\ ${ }^{*}$ Corresponding author. Email: mayalestari270482@gmail.com
}

\begin{abstract}
The hypothesis in this study were there is an effect of work motivation on the performance of elementary school teachers at Cempaka sub-district of OKU Timur district, there is an effect of compensation on the performance of elementary school teachers at Cempaka sub-district of OKU Timur district, and there is an influence of work motivation and compensation together on the performance of elementary school teachers at Cempaka sub-district of OKU Timur district. The researcher collects the data by using observation, interviews and questionnaires. The analysis is used the correlation analysis of the $\mathrm{t}$ test and the $\mathrm{F}$ test. The results of the data analysis are there is an effect of work motivation on the performance of public elementary school teachers at Cempaka sub-district of OKU Timur district, there is an effect of compensation on the performance of public elementary school teachers at Cempaka subdistrict of OKU Timur district, and there is an effect of Work Motivation and Compensation together on the performance of Public Elementary School teachers in at Cempaka sub-district of OKU Timur district.
\end{abstract}

Keywords: Motivation, Compensation, Performance

\section{INTRODUCTION}

One of the factors that usually becomes a problem in a company is human resource management. Personnel management is closely related to teachers in carrying out their daily duties and responsibilities. This happened in elementary school of Cempaka, OKU Timur district, where teacher performance had not shown optimal results.

The successful implementation of the responsibility and accountability in elementary school of Cempaka, OKU Timur district can only be achieved with the support of qualified, creative, disciplined, dedicated and loyal personnel. Performance is the result of a person's work in quality and quantity in carrying out their functions according to their responsibilities to the organization or institution. So, this performance is related to the efforts made by a person to achieve the expected work results. Whether the performance is good or not depends on the results obtained by a teacher in carrying out his functions in an institution, whether the results of the performance of his function are in accordance with his goals and expectations. It can be said that the teacher's performance, but if the teacher's job does not meet expectations and goals then it can be said that the performance is not good. A person's performance is not only based on the results he gets, but is also related to human behavior in the world of work itself, or it can be said that performance is an act of a process which includes several components of sport. From this definition of achievement, the writer can refer to the achievement of teachers in elementary school in Cempaka of OKU Timur District, namely the quality and quantity of work that leads to the completion of their assignments.

In terms of quality and quantity, the performance of the teachers of elementary school of OKU Timur District must be able to bring changes to the achievement of institutional goals so that it can be said that the performance of the teachers is good. Likewise, in the implementation of daily tasks, for example the presence of teachers in various institutional activities, work planning and the quality of work produced, and what is no less important is the coordination of fellow teachers in carrying out tasks.

To get good performance from these teachers, they continue to try to find solutions and what factors can improve the performance of these teachers. So according to the author, perhaps one of the factors that can also improve the performance of elementary school at Cempaka sub-district of OKU Timur district is to 
increase work motivation and provide compensation to school teachers. In carrying out its duties, elementary school teachers at Cempaka sub-district of OKU Timur district are expected to bring changes. towards teachers at work. As a result of temporary observations by researchers that the performance of elementary school teachers at Cempaka sub-district of OKU Timur district has not been optimal, this can be seen in the results of work completed by teachers who often do not match what was promised in following up on the decree, elementary school at Cempaka sub-district of OKU Timur district has made system improvements management, especially to motivate teachers to work so they can produce achievement and in the end the teacher gets the expected work results.

To achieve this, elementary school at Cempaka subdistrict of OKU Timur certainly has a heavy burden because so far the teacher's achievements have not yielded satisfactory results. Apart from these problems, elementary school at Cempaka sub-district of OKU Timur. You also experience problems with administrative staff or teachers, because the performance of elementary school at Cempaka subdistrict of OKU Timur is currently not showing optimal results because there are still teachers. who often do not come to work or are late with the percentage of $6 \%$. (Documentation 20019/2020).

Teachers who are late or not during working hours often become obstacles in institutional activities. Therefore, elementary school at Cempaka sub-district of OKU Timur continues to strive to reduce teachers who are often late or absent. Just like the willingness of teachers to work, there are still teachers who work as is. At elementary school at Cempaka sub-district of OKU Timur, only $90 \%$ of teachers are truly ready to play (2019/2020 documentation). The willingness of teachers to work is very important because after all a teacher certainly hopes to finish his homework properly. This is very detrimental to elementary school at Cempaka subdistrict of OKU Timur.

From these problems, the question arises for researchers why teachers tend to be late and why the willingness of teachers to work is not as expected, this may be due to teachers feeling less attention and not respecting teachers. They work and are not happy with what they have done. Performance in general can be interpreted as a teacher's attitude towards his job. Someone who is satisfied with his job will have a positive attitude towards the organization or institution where he works. So far, those who are not happy with their work will tend to have a negative attitude towards the institution or organization where they work.

School compensation is very important to improve teacher performance. This will have a negative impact on the teacher himself. Low morale, lack of motivation, less enthusiasm, inadequate performance of work tasks and in the end will lead to other negative behaviors. A person will be satisfied with what he has done if the results of his work are in accordance with his wishes. conducive, the attention of superiors for what they have done, reward for performance in the workplace, good communication between superiors, subordinates and subordinates by means of the means used in the workplace can affect performance. Someone who gets job satisfaction will then try to work better than before so that in the end it can improve their performance.

Apart from the problems raised by the researchers, another problem is that around $10 \%$ of teachers at elementary school at Cempaka sub-district of $\mathrm{OKU}$ Timur are looking for additional work by looking for additional work because their income is not sufficient.

If a teacher works too hard it will clearly affect his working hours at elementary school at Cempaka subdistrict of OKU Timur as his job. If this happens with more than one teacher, the process of completing assignments at elementary school at Cempaka subdistrict of OKU Timur may be left behind. Therefore, in responding to this tries to make the current teachers really pay attention to their work at elementary school at Cempaka sub-district of OKU Timur. For this reason, the elementary school at Cempaka sub-district of OKU Timur. trying to add or add rewards to teachers in carrying out their duties at elementary school at Cempaka sub-district of OKU Timur, can be increased, because in addition to the salary provided by the government at elementary school at Cempaka subdistrict of OKU Timur, it receives additional incentives. The hope is that the good performance of the teachers of elementary school at Cempaka sub-district of OKU Timur will bring the good name of the institution so that elementary school at Cempaka sub-district of $\mathrm{OKU}$ Timur can be proud.

Seeing this situation, the author is interested in examining why elementary school teacher at Cempaka sub-district of OKU Timur do not perform optimally when they are not satisfied with what they have been doing so far. because they are working as is and why are some teachers working as extra assignments, right? The work motivation of elementary school teacher at Cempaka sub-district of OKU Timur to improve their performance is still low or the salary received by teachers of elementary school at Cempaka sub-district of OKU Timur is insufficient. Hence, more research is needed.

Motivation is someone's desire that makes that person act. Someone usually acts for something, of course for the achievement of a goal. So motivation is the driving force leading up to this goal and is rarely neglected. Motivation is a set of conditions that exist within a person and functions to activate or shape behavior. Then the behavior is directed to achieve the goal and maintain it until the desired goal is achieved. It is believed that high work motivation on the part of the teacher leads to maximum performance, because teachers who are motivated to work try to make their work run well, because there is a need in life for 
satisfaction such as achievement or recognition of the results obtained.

One of the ways taken by elementary school at Cempaka sub-district of OKU Timur in motivating teachers to carry out their duties is by filling outstanding teacher positions that allow them to continue their education, thank you for your dedication. Giving rewards to institutions and increasing the income of these teachers by providing incentives in addition to the salary they receive, etc., so that teachers can fully focus on their main tasks at elementary school at Cempaka sub-district of OKU Timur.

Besides being able to increase the work motivation of teachers at elementary school at Cempaka sub-district of OKU Timur, it is also believed to be able to improve teacher performance. Another way to improve teacher performance is to increase the salaries that these teachers receive. Teachers receive compensation in return for their contribution to the organization.

Compensation is a strategic HR function that has a significant impact on other HR functions. Compensation is an important factor affecting how and why people work in an organization and not in another, so companies must be competitive enough with some type of compensation to maintain, hire and reward each individual's performance. Within the organization. The explanation described above should have a clearer picture of what compensation actually means. However, as an important part of human resource management, it is necessary to provide a stronger and more stable definition or definition. What is clear is that the term "compensation" has a broader scope than just the provision of "wages and salaries", the concept of wages and salaries emphasizes remuneration that is purely "financial", while compensation includes both financial and non-financial remuneration.

From this description, the authors are interested in seeing how much influence teacher work motivation and compensation given by elementary school at Cempaka sub-district of OKU Timur on teacher performance in carrying out their duties. So that the author wants to research with the research title The Effect of Work Motivation and Compensation on the Performance of elementary school teacher at Cempaka sub-district of OKU Timur.

Performance is a tool to provide information to teachers or workers and their superiors about how someone does their job or job [1]. By knowing their own performance, individuals can see their abilities and abilities in doing a job compared to the responsibilities given to them or others. Performance is a continuous process to see the quality of staff and efforts to improve staff performance in the organization. Through this evaluation, we can find out whether the position is in accordance with the job description that has been prepared previously [2].
Explains that individual characteristics are the weakest criteria for assessing teacher performance, but are still widely used by organizations. It is said to be the weakest individual job because it is far from real work, such as having a good attitude, trust, reliable cooperation, lots of experience; it cannot directly correlate with positive employment outcomes [3]. Job evaluation is the process of starting the work of staff in an organization through performance appraisal instruments, job initiation assessing staff performance by comparing standard performance standards.

From some of the opinions above, it can be concluded that performance is something that is created and produced as a product or service for a certain period of time and by a dependent person or group of people. their skills, abilities, knowledge and experience.

That "motivation is the character of the individual to make great efforts to achieve organizational goals". If someone is motivated, they will do their best to achieve their goals, but not necessarily big effort will result in high performance [4]. Therefore, it requires the intensity and quality of these efforts, as well as a focus on organizational goals. Internal conditions that provoke impulses, where unmet needs will create tension that stimulates impulses in the individual. This impulse results in search behavior to find a specific target. If there is a need, stress will be reduced. The motivated employee is in a tense state and tries to reduce the tension by trying to come back refreshed.

This motivation is an important problem for managers, because by definition managers must work with other people. Managers must understand the behavior of certain people to influence them to work in accordance with the wishes of the organization [5].

Suggests that a theoretical approach to motivation that affects and changes work behavior is the formation of behavior or often referred to as behavior change, positive reinforcement, and Skinnerian conditioning. This approach is primarily based on the law of consequences, which states that behavior followed by pleasant consequences tends to be repeated, whereas behavior followed by punitive consequences tends not to be repeated. Thus, individual behavior in the future can be predicted. or learn from past experiences.

From several definitions of work motivation, it can be synthesized that a person has high achievement motivation, if he has the desire to perform better than others in many situations. Mc Clelland focuses on three human needs, which are defined as follows: Mc Clelland's motivation, among others: Affiliation motivation, Achievement and Power.

Compensation is a form of appreciation that is given by the company to employees in return for remuneration for labor or contributions made by employees for the advancement and achievement of company goals [6]. The factors that affect the amount of compensation received by employees as described include paying 
attention to and considering labor market conditions, regulations set by the government regarding compensation policies, work agreements with employees [7]. The benefits obtained by providing compensation stated are that this compensation is believed to be able to improve employee work performance in the company, employees will be more enthusiastic in carrying out the work given to them, motivation at work will increase [8].

Two measuring tools or approaches that can be used in providing compensation by a company, namely normative measuring tools and policy measuring tools [9]. Where this normative compensation includes salaries or wages and fixed components that have been determined by the company from its inception, allowances received by employees during religious / religious holidays and health benefits for employees and their families. Meanwhile, compensation is policy in nature, namely compensation provided by companies based on special considerations, including food allowances received by employees every time they come to work and transport, bonus / incentive allowances, leave and vacation pay.

From the above description, it can be synthesized that compensation is any form of reward received by a teacher as a return for their efforts, either in the form of direct financial compensation or indirect financial compensation. Direct financial compensation includes salaries, wages, commissions and bonuses that can be received by teachers directly in the form of money, while indirect financial compensation includes allowances, insurance, support costs for education, payments when not working, sickness, vacation and so on can be accepted by the teachers indirectly.

\section{METHODS}

The research location was conducted at the elementary school at Cempaka sub-district of OKU Timur.
In this study, the authors used quantitative data, namely research that is required to use numbers, starting from data collection, interpretation of data, and the appearance of the results. Quantitative research is a type of research whose specifications are systematic, planned, and clearly structured from the start to the making of the research design.

Population a "generalization area consisting of objects or subjects that have certain quantities and characteristics that are expected by researchers to study and then draw conclusions." The population that became the object of the study were all elementary school teachers in elementary school at Cempaka sub-district of OKU Timur, totaling 22 elementary schools with 266 teachers.

The sample is part or representative of the population under study. To determine the size of the sample if the subject is less than 100 , it is better to take all of them so that the research is population research. If the subject is bigger it can be taken between $20-25 \%$ [10].

Based on these opinions and to save time, cost and energy, in this study the researchers only took 58 people.

In this study the authors used quantitative data, namely research that is required to use numbers, starting from data collection, interpretation of the data, and the appearance of the results. To collect research data, the authors used observational methods, questionnaires and documentation.

\section{RESULTS AND DISCUSSION}

1) Hypothesis Testing of Work Motivation $\left(X_{1}\right)$ on Performance (Y)

\begin{tabular}{|c|c|c|c|c|c|}
\hline \multirow{3}{*}{ Model } & \multicolumn{5}{|c|}{$\begin{array}{l}\text { Table 1. Significance of Work Motivation on } \\
\text { teacher work performance }\end{array}$} \\
\hline & \multicolumn{2}{|c|}{$\begin{array}{l}\text { Unstandardized } \\
\text { Coefficients }\end{array}$} & \multirow{2}{*}{$\begin{array}{c}\begin{array}{c}\text { Standardized } \\
\text { Coefficients }\end{array} \\
\text { Beta }\end{array}$} & \multirow[t]{2}{*}{$t$} & \multirow[t]{2}{*}{ Sig. } \\
\hline & B & $\begin{array}{l}\text { Std. } \\
\text { Error }\end{array}$ & & & \\
\hline 1 (Constant) & 0.047 & 7.260 & & 0.006 & 0.995 \\
\hline $\begin{array}{l}\text { Work } \\
\text { Motivation }\end{array}$ & 0.817 & 0.089 & 0.768 & 9.189 & 0.000 \\
\hline
\end{tabular}

From the table above, the $\mathrm{t}$ value is 9,189 with a sig 0,000 . Because the sig value is less than 0.05 , the hypothesis which says there is an effect of work motivation on the performance of elementary school at Cempaka sub-district of OKU Timur is accepted. This means that work motivation affects the performance of elementary school at Cempaka sub-district of OKU Timur.

2) Compensation Hypothesis Testing $\left(\mathbf{X}_{2}\right)$ on Performance (Y). 
Table 2. Significance of Hypothesis Testing $\left(\mathbf{X}_{2}\right)$ on Performance (Y)

\begin{tabular}{|c|c|c|c|c|c|}
\hline \multirow[b]{2}{*}{ Model } & \multicolumn{2}{|c|}{$\begin{array}{l}\text { Unstandardized } \\
\text { Coefficients }\end{array}$} & \multirow{2}{*}{$\begin{array}{c}\text { Standardized } \\
\text { Coefficients } \\
\text { Beta } \\
\end{array}$} & \multirow[b]{2}{*}{$\mathrm{t}$} & \multirow[b]{2}{*}{ Sig. } \\
\hline & B & $\begin{array}{l}\text { Std. } \\
\text { Error }\end{array}$ & & & \\
\hline 1 (Constant) & 1.822 & 5.722 & & 0.318 & 0.751 \\
\hline Compensation & 0.769 & 0.070 & 0.835 & 11.338 & 0.000 \\
\hline
\end{tabular}

a. Dependent Variable: Teacher Performance

From the table above, the $\mathrm{t}$ value is 11,338 with a sig level of 0,000 . Because the sig value is less than 0.05 , the hypothesis that there is an effect of compensation on the performance of elementary school at Cempaka sub- district of OKU Timur is accepted. This means that compensation affects the performance of elementary school at Cempaka sub-district of OKU Timur.

3) Hypothesis Testing Work Motivation $\left(\mathrm{X}_{1}\right)$ and Compensation $\left(\mathrm{X}_{2}\right)$ on Performance (Y)

Table 4. The results of multiple regression analysis Work Motivation (X1) and Compensation (X2) on Performance (Y)

\begin{tabular}{|c|c|c|c|c|c|}
\hline Model & $\begin{array}{c}\text { Sum of } \\
\text { Squares }\end{array}$ & df & $\begin{array}{l}\text { Mean } \\
\text { Square }\end{array}$ & $\mathrm{F}$ & Sig. \\
\hline Regression & 1336.357 & 1 & 1336.357 & 128.556 & $.000^{\mathrm{b}}$ \\
\hline Residual & 582.126 & 56 & 10.395 & & \\
\hline Total & 1918.483 & 57 & & & \\
\hline
\end{tabular}

a. Dependent Variable: Teacher Performance

b. Predictors: (Constant), Work Motivation, Compensation

From the table above, the $\mathrm{F}$ value is 128,556 with a sig level of 0,000 . Because the sig value is less than 0.05 , the hypothesis that there is an effect of work motivation and compensation on the performance of public elementary school teachers in Cempaka, OKU Timur district is accepted.

\section{CONCLUSION}

Based on the results of research and data analysis that has been done descriptively and hypothesis testing can be concluded as follows: There is an effect of Work Motivation on the performance of elementary school at Cempaka sub-district of OKU Timur, There is a Compensation effect on the performance of elementary school at Cempaka sub-district of OKU Timur, There is an effect of Work Motivation and Compensation together on the performance of elementary school at Cempaka sub-district of OKU Timur.

For researchers to follow up further on the results of this study by developing independent variables that can improve the performance of public elementary schools in Cempaka District, OKU Timur District. This needs to be done because there are still other factors that have an influence on teacher performance besides work motivation and compensation because only $69.9 \%$ of teacher performance is determined by work motivation and compensation, meaning $31.1 \%$ is determined by factors outside work motivation and compensation such as compensation, satisfaction. work and others.

\section{ACKNOWLEDGMENTS}

Our deepest gratitude goes to Chancellor of Palembang PGRI University, Director of the Postgraduate Program of PGRI Palembang University and the Education Management Study Program of PGRI Palembang University, who have supported us in doing this extraordinary thing. This project is funded independently. We also want to thank our Education Management friends who helped us a lot in a short time frame to complete this project.

\section{REFERENCES}

[1] Dharma, A. (2011). Manajemen Prestasi Kerja [Work Performance Management]. Jakarta: Rajawali Pers.

[2] Simamora, H. (2017). Manajemen Sumber Daya Manusia [Human Resource Management]. Jakarta: Bumi Aksara.

[3] Robbins, S. P. (2001). Perilaku Organisasi [Organizational Behavior]. Jakarta: PT Indeks. 
[4] Robbins, S. P. (2002). Essentials of Organizational Behavior. New Jersey: Prentice-Hall.

[5] Brantas. (2009). Dasar-Dasar Manajemen [Fundamentals of management]. Bandung: Alfa Beta.

[6] Sinambela, L. P. (2016). Manajemen Sumber Daya Manusia: Membangun. Tim Kerja yang Solid untuk Meningkatkan Kinerja [Human Resource Management: Building. Solid Work Team to Improve Performance]. Jakarta: Bumi Aksara.

[7] Marwansyah. (2016). Manajemen Sumber Daya Manusia Edisi Kedua [Human Resource Management Second Edition]. Bandung: Alfabeta.

[8] Erwinsyah. (2015). Motivasi Berpengaruh Tidak Signifikan Terhadap Kinerja Karyawan [Motivation has no significant effect on employee performance]. Jakarta: PT Indeks.

[9] Edison, S. (2010). Manajemen Sumber Daya Manusia: Reformasi Birokrasi dan Manajemen Pegawai Negeri Sipil [Human Resource Management: Bureaucratic Reform and Civil Servant Management]. Bandung: Refika Aditama.

[10] Arikunto, S. (2013). Metode Penelitian [Research methods]. Jakarta: Rineka Cipta. 